\title{
REFORMASI BIROKRASI MELALUI PENATAAN KELEMBAGAAN PADA SEKRETARIAT DAERAH KOTA KENDARI
}

\author{
Oleh: \\ Ning Ndri Ayu Toimsar ${ }^{1}$, Muhammad Basri², La Manguntara ${ }^{3}$ \\ ${ }^{1}$ Mahasiswa Jurusan Ilmu Administrasi Publik, Fakultas Ilmu Sosial dan Ilmu Politik, UHO \\ ${ }^{2.3}$ Dosen Jurusan Ilmu Administrasi Publik, Fakultas Ilmu Sosial dan Ilmu Politik, UHO

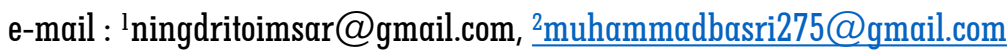

\begin{abstract}
The purpose of this study was to determine : (1) Implementation of Bureaucratic Reform through Institutional Arrangement at the Regional Secretariat of Kendari City, (2) Factors Affecting the Implementation of Bureaucratic Reform Through Institutional Arrangement at the Regional Secretariat of Kendari City. The location of this study is the Regional Secretariat of Kendari City, JI. Drs. H Abdullah Silondae No. 8 Kendari City. The type of this study is Qualitative Description. The informants in this study were 6 people who were employees of the Regional Secretariat of Kendari City. Data collection techniques in this study were observation, interviews and document studies. Data Analysis techniques of the study were form of data collection, data reduction, data display or data presentation, and drawing conclusions. The results showed that the Implementation of Bureaucratic Reform through Institutional Arrangement at the Kendari City Secretariat was viewed from the dimensions of structur and culture (work culture) of the bureaucracy. Factors that influence the Implementation of Bureaucratic Reform in the Regional Secretariat of Kendari City are Effectiveness, Efficiency and Productivity of the Regional Devices Organization of Kendari City, the Process of Delegating Apparatus Authority to officials below, and Bureaucratic Culture. As a government actor, bureaucrats are expected to be able to run the bureaucratic arrangement as well as possible following the principles of reform proclaimed to achieve a clean, effective, efficient, productive and highly competitive bureaucracy in order to realize the bureaucratic reform that has been aspired so far.
\end{abstract}

\section{Keywords : Bureaucratic Reformation, Institutional Arrangement, Structure and Bureaucratic Culture}

\section{PENDAHULUAN}

Birokrasi di Indonesia, baik di tingkat Pusat maupun di tingkat Daerah, pasca reformasi kerap mendapat sorotan dan kritik yang tajam baik karena struktur kelembagaan yang gemuk dan menyerap banyak pendanaan yang tidak sesuai dengan kebutuhan masyarakat, maupun karena perilaku aparatur yang tidak sesuai dengan tugas yang diembannya sebagai pelayan masyarakat. Sehingga apabila orang berbicara tentang birokrasi senantiasa berkonotasi negatif. Birokrasi selalu diasosiasikan lamban, berbelit-belit, menghalangi kemajuan, cenderung memperhatikan prosedur dibandingkan substansi, dan tidak efesien. Bahkan pandangan para pengamat lebih jauh lagi tentang model birokrasi di Indonesia. Padahal, di setiap negara, birokrasi memegang peranan penting karena ia menjalankan keputusan politik atau kebijakan pemerintah. Karena itu, birokrasi hendaknya didesain seefektif dan seefisien mungkin agar optimal dalam menjalankan fungsi.

Reformasi birokrasi adalah perubahan besar dalam paradigma dan tata kelola pemerintahan untuk menciptakan birokrasi pemerintah yang profesional dengan karakteristik adaptif, berintegritas, bersih dari perilaku korupsi kolusi dan nepotisme, mampu melayani publik secara akuntabel, serta memegang teguh nilainilai dasar organisasi dan kode etik perilaku aparatur negara. Reformasi birokrasi didasari atas Peraturan Presiden Republik Indonesia Nomor 81 Tahun 2010 tentang Grand Desain Reformasi Birokrasi 2010-2025. 
Lingkungan kerja di seluruh Kementerian/Lembaga/Pemerintah Daerah perlu melakukan reformasi birokrasi (Berdasarkan Peraturan Presiden Republik Indonesia Nomor 81 tahun 2010 tentang Grand Design Reformasi Birokrasi 2010-2025).

Pengetahuan tentang reformasi birokrasi dan pemahaman akan pentingnya untuk melakukan perubahan ditubuh birokrasi sangat diperlukan. Oleh karenanya banyak penelitian yang mengulas tentang reformasi birokrasi di tubuh pemerintahan. Salah satu penelitian relevan yang pernah dilakukan ialah reformasi birokrasi sektor kesehatan di Kota Kendari. Penelitian tersebut menerangkan tentang masih sangat kurangnya kesadaran dan implementasi reformasi birokrasi. Sesuai fakta yang terjadi di lokasi penelitian, peneliti menyimpulkan bahwa birokrasi sektor kesehatan Kota Kendari tidak reform. Hal ini menunjukan bahwa perlu adanya pendalaman kasus mengenai reformasi birokrasi khususnya di tubuh pemerintahan yang merupakan unsur pengawal perubahan ke arah kesejahteraan masyarakat.

Faktor lain yang juga menjadi pendorong ialah dikeluarkannya Kebijakan Permenpan dan RB NO. 20 TAHUN 2010 tentang Roadmap Reformasi Birokrasi 2010-2014 mendorong perbaikan jalannya birokrasi agar lebih efektif dan efisien baik di pusat maupun di daerah. Namun, kebutuhan akan adanya perbaikan secara keseluruhan dan mendalam itu paling dirasakan ditinngkat daerah yang notabene adalah yang paling dekat dan berhadapan secara langsung dengan masyarakat. Secara skala kenegaraan, daerah memang hanya sebagai pendukung suksesnya kebijakan di pusat, akan tetapi secara peranan kesejahteraan, daerahlah yang menjadi tonggak awal penentunya. Dengan besarnya peran pemerintah daerah dalam mensejahterakan rakyat, oleh karenanya diperlukan unit kerja yang juga memadai dan sanggup melakukan tugas besar tersebut yang memang bisa menjadi wadah penyaluran aspirasi masyarakat dan membantu masyarakat dalam segala bidang kehidupan.

Kota Kendari ialah daerah yang dalam pelaksanaan birokrasinya juga menjalankan reformasi yang tertuang di dalam dokumen Road Map Reformasi Birokrasi Kota Kendari dengan jangka waktu 5 tahun. Dalam kerangka Roadmap itu sendiri dalam hal ini Roadmap Reformasi Birokrasi Kota Kendari tahun 2015-2019 masih terdapat berbagai kekurangan dan permasalahan birokrasi di Kota Kendari yang begitu kompleks. Dari segi Kelembagaan misalnya, yaitu seperti penempatan pegawai yang belum sesuai dengan syarat jabatan, belum lagi masalah lambatnya proses penempatan pejabat devinitif saat adanya pergantian atau pensiun pegawai pemegang jabatan yang bersangkutan. Juga masalah lain seperti Kualitas SDM Aparatur, sampai pada sarana dan prasarana yang kurang memadai.

Dalam hal kelembagaan, pada struktur kelembagaan perangkat daerah yang paling tinggi, yaitu Sekretariat Daerah Kota Kendari. Berdasarkan UU No. 23 Tahun 2004 dalam BAB VIII tentang Perangkat Daerah yang kemudian ditindaklanjuti oleh PP No. 18 Tahun 2016 tentang Perangkat Daerah, Sekretariat Kota Kendari ialah yang bertugas langsung dibawah walikota dan wakil walikota, yang memegang peranan paling utama dari susunan perangkat daerah. Berlanjut ke PERDA Kota Kendari No. 5 Tahun 2016 tentang Pembentukan Dan Susunan Perangkat Daerah Kota Kendari yang juga langsung ditindaklanjuti oleh PERWALI No. 36 Tahun 2016 tentang Kedudukan, Susunan Organisasi, Tugas Dan Fungsi Serta Tata Kerja Sekretariat Daerah Kota Kendari, terdapat uraian lengkap tugas pokok dan fungsi dri sekretariat Kota Kendari yang begitu kompleks yang terbagi atas 3 asisten yang terdiri atas 12 bagian serta staf ahli dan kelompok jabatan fungsional yang juga bertugas di bawah walikota.

Dengan kompleksnya tupoksi dari sekretariat Kota Kendari serta besarnya tanggung jawab yang diemban demi pelayanan yang prima untuk masyarakat di Kota Kendari, pada masing-masing bagian dan sub bagian dalam kelembagaan Sekretariat Kota Kendari sendiri, haruslah benar-benar melalui penataan yang baik. Konsep penataan kelembagaan pun harus dipahami secara mendalam sesuai dengan prinsip Reformasi Birokrasi bagi 
para Stake-holder dan seluruh jajaran staf yang bukan hanya sekedar pemahaman tentang perbaikan struktur organisasi, namun juga pertimbangan soal sumber daya manusia yang berkualitas juga penyederhanaan ketatalaksanaan yang kesemuanya membutuhkan koordinasi satu sama lain.

Dengan demikian, ada dua yang menjadi rumusan masalah pada penelitian ini, yaitu sebagai berikut : Bagaimana Pelaksanaan Reformasi Birokrasi dalam Menunjang Penataan Kelembagaan Pada Sekretariat Daerah Kota Kendari? Dan Faktor-Faktor Apa Saja Yang Mempengaruhi Pelaksanaan Reformasi Birokrasi Melalui Penataan Kelembagaan Pada Sekretariat Daerah Kota Kendari?

\section{METODE PENELITIAN}

Penelitian ini telah dilaksankan di Sekretariat Daerah Kota Kendari Kendari yang berlokasi di Jl. Drs. H Abdullah Silondae No. 8 Kota Kendari. Pemilihan lokasi penelitian ini didasari oleh pertimbangan bahwa Sekretariat Derah Kota Kendari merupakan Jantung Pemerintahan Kota Kendari dan merupakan pusat penataan kelembagaan yang begitu kompleks dalam skala Kota sebagaimana Uraian tupoksi dari Sekretariat Daerah Kota Kendari dalam lembaran Peraturan Walikota Kendari. Juga mengingat belum pernah ada penelitian serupa tentang Reformasi Birokrasi yang dilakukan di lokasi tersebut sehingga dengan adanya penelitian tentang reformasi birokrasi pada tataran kelembagaan Kantor Walikota Kendari, akan mampu memberikan manfaat besar baik secara teoritis maupun praktis.

Informan dalam penelitian ini berjumlah 6 orang yang merupakan pegawai Sekretariat Daerah Kota Kendari yaitu Sekretaris Daerah, Assisten Administrasi Umum dan Kepala Bagian Adm. Organisasi, dan Pemberdayaan Aparatur yang membawahi 3 Sub Bagian yang ada di bawahnya antara lain Kepala Sub Bagian Kelembagaan dan Analisis Jabatan, Kepala Sub Bagian Tata Laksana dan Reformasi Birokrasi, Kepala Sub Bagian Pemberdayaan Aparatur. Para informan yang dipilih dalam penelian ini ialah yang dinilai paling mengetahui mengenai obyek penelitian serta mampu memberikan informasi yang dibutuhkan oleh peneliti terkait penelitian yang akan dilakukan.

Jenis dan sumber data pada penelitian ini yaitu : Data primer, berupa hasil wawancara yang diperolah dari wawancara dan observasi langsung di lokasi penelitian dan Data Sekunder, berupa soft copy dokumen program kerja Bagian Adm. Organisasi, dan Pemberdayaan Aparatur dan soft copy Road Map Reformasi Birokrasi Kota Kendari pada 5 tahun terakhir yang diperoleh dari informan di lokasi penelitian.

Teknik pengumpulan data dalam penelitian ini menggunakan teknik obsevasi, wawancara dan studi dokumen. Adapun observasi dilakukan untuk meninjau serta memepelajari situasi dan kondisi Sekretariat Kota Kendari untuk kemudian menjadi bahan acuan untuk melanjutkan pada tahap wawancara kepada pihak-pihak yang terkait dengan sasaran dan inti permasalahan yang diteliti. Kemudian, dokumen yang diperoleh dari observasi pendahuluan menjadi bahan kajian untuk menemukan kondisi dan masalah pada Sekretariat Kota Kendari.

Teknik analisis data yang akan digunakan dalam penelitian ini adalah teknik analisis data model interaktif milik Miles \& Huberman yang meliputi : Tahap Pengumpulan Data, Reduksi Data, Display Data, dan Penarikan Kesimpulan/Verifikasi.

\section{PEMBAHASAN}

\section{Reformasi Birokrasi Melalui Penataan Kelembagaan}

Berdasarkan teori Fountain (2007) Reformasi Birokrasi melalui penataan kelembagaan pada Sekretariat Daerah Kota Kendari ialah modifikasi-modifikasi dan perbaikan-perbaikan institusional, organisasional dan prosedural dalam birokrasi pemerintah guna meningkatkan responsivitas terhadap warganegara serta memperbaiki efisiensi dan efektivitas organisasi atau kelembagaan dengan melalui Penataan kelembagaan. 
Penataan kelembagaan yang dilakukan yaitu suatu penataan hubungan antara unit-unit yang juga mengatur cara unit-unit ini bekerja sama untuk mencapai tujuan yang telah disepakati bersama dan menjadi cita-cita bersama. Ada beberapa hal atau yang menunjukan adanya suatu perubahan atau reformasi dalam tubuh birokrasi yaitu sebagai berikut : Pengembangan penyusunan struktur organisasi perangkat daerah yang selalu disesuaikan dengan kebutuhan urusan pemerintah.

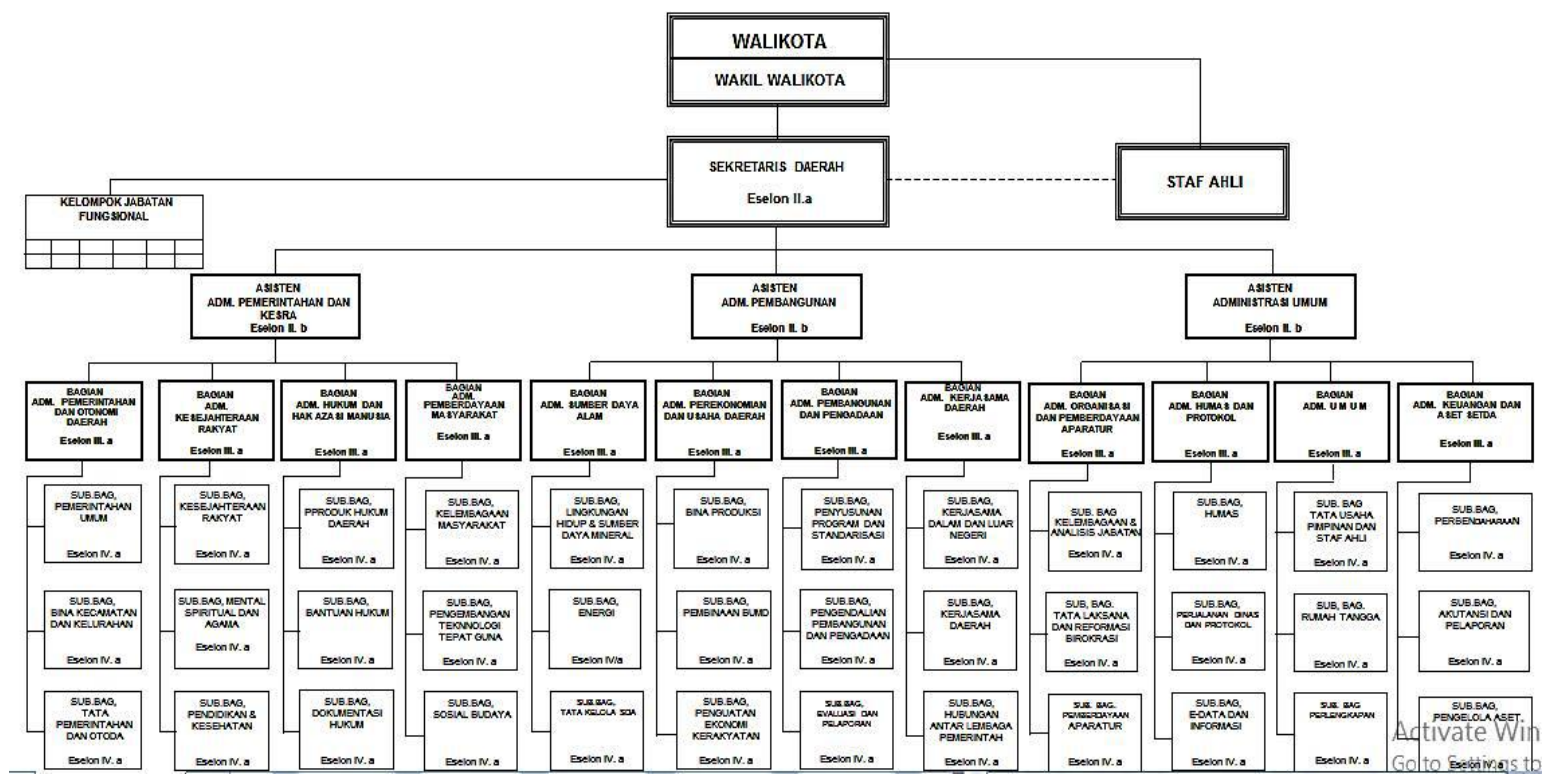

\section{Gambar 1. Bagan Struktur Sekretariat Daerah Kota Kendari}

Pelaksanaan reformasi birokrasi pada melalui penataan kelembagaan sesuai teori Thoha (2006) yang meliputi Struktur Kelembagaan, Sistem yang digunakan dan perilaku SDM atau kultur birokrasi.

Saat ini, pola struktur yang digunakan oleh Sekretariat Daerah Kota Kendari ialah pola maksimal 12 bagian. Dalam pelaksanaannya, dikatakan efektif karena struktur dengan pola maksimal tersebut menjadikan tidak ada urusan pemerintahan yang tidak diurusi oleh pemerintah. Salah satu bentuk perubahan atau perbaikan yang dilakukan ialah penambahan pada bagian Kesra (Kerjasama Daerah). Sebelumnya, bagian Kerjasama Daerah tidak terdapat atau tidak tercantum dalam struktur kelembagaan. Namun kini dengan berbagai pertimbangan akan adanya urusan kerjasama antar daerah, maka dibentuklah Bagian Kerjasama Daerah.

Sistem penyederhanaan ketatalaksanaan senantiasa terus dikembangkan dalam penyelenggaraan kelembagaan pada sekretariat daerah Kota Kendari sesuai dengan teori Sedarmayanti (2008) merangkumnya dengan ciri-ciri penyederhanaan ketatalaksanaan sebagai berikut :

1. Mempunyai strategi yang jelas.

2. Organisasi flat atau ditoleransikan bersifat datar

3. Organisasi ramping atau tidak terlalu banyak pembandingan secara horisontal.

4. Organisasi bersifat jejaring (networking)

5. Organisasi bersifat fleksibel dan adaptif.

6. Organisasi banyak diisi jabatan fungsional.

7. Organisasi menerapkan strategi "learning organization" 


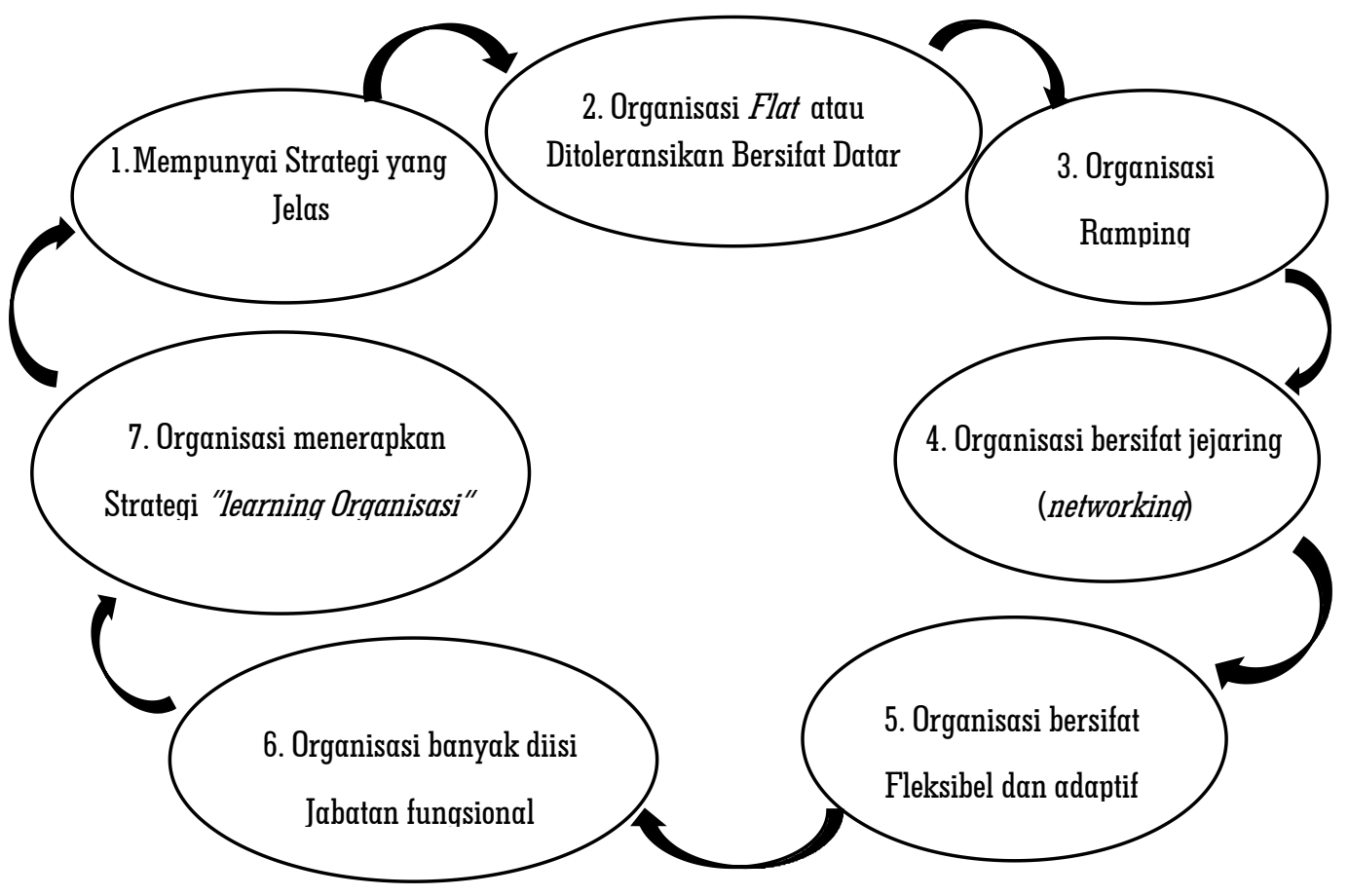

Gambar 2. Teori Penyederhanaan Ketatalaksanaan

Sistem pengendalian yang digunakan dalam pelaksanaan Pemerintah Kota Kendari saat ini ialah Sistem Pengendalian Intern Pemerintah (SPIP), yang akan terus dikembangkan. Juga Dalam rangka kejelasan prosedur pelayanan maka seluruh SKPD telah memiliki Standar Operasional Prosedur (SOP) yang ditetapkan baik melalui Peraturan Walikota, Keputusan Walikota, maupun Keputusan Kepala SKPD. Selain itu, Seluruh SKPD/unit kerja di lingkungan Pemerintah Kota Kendari menyediakan sarana pengaduan untuk penyampaian informasi terkait pelayanan publik, dimana masyarakat dapat langsung menyampaikan pengaduannya melalui telepon, SMS, kotak pengaduan maupun internet.

Dalam hal pengembangan SDM aparatur, sesuai dengan cita-cita reformasi birokrasi yaitu upaya mewujudkan pemerintahan yang bersih dan bebas KKN hal ini jugalah yang senantiasa dilakukan oleh pemerintah Kota Kendari. Dalam hal peningkatan kualitas, berbagai upaya perbaikan senantiasa dilakukan dengan adanya sasaran-sasaran pencapaian dalam kinerja aparat. Selain itu juga Pemberian reward dan punishment bagi pegawai yang berprestasi dan pegawai yang melakukan pelanggaran. Hal ini diluar dari masih saja adanya berbagai hambatan dalam pengembangan SDM Aparatur yaitu Masih banyak petugas pelayanan yang memiliki tugas rangkap sehingga memperlambat pelayanan; Penempatan pegawai belum sesuai dengan syarat jabatan; Masih kurang disiplinnya PNS, dan kurang kompetensi dalam jabatan yang di emban; Namun, perbaikan senantiasa terus dilakukan demi tercapainya tujuan besar dari Reformasi Birokrasi.

Faktor-Faktor yang Memperngaruhi Reformasi Birokrasi Melalui Penataan Kelembagaan

Dalam mencapai terlaksananya reformasi dalam sebuah birokrasi kelembagaan, ada beberapa faktor penting yang perlu diperhatikan yaitu :

\section{Struktur Birokrasi}

Struktur organisasi perangkat daerah Sekretariat Daerah Kota Kendari Kota Kendari diatur secara keseluruhan diatur dalam Peraturan Pemerintah No. 18 Tahun 2016 tentang Perangkat Daerah yang kemudian ditindaklanjuti pemerintah Kota Kendari dengan penetapan Peraturan Daerah No. 5 Tahun 2016 tentang Pembentukan Dan Susunan Perangkat Daerah Kota Kendari yang juga ditindaklanjuti oleh Peraturan Walikota 
Kendari No. 36 Tahun 2016 tentang Kedudukan, Susunan Organisasi, Tugas Dan Fungsi Serta Tata Kerja Sekretariat Daerah Kota Kendari.

Penyusunan Struktur organisasi Perangkat Daerah Kota Kendari, secara keseluruhan telah memenuhi syarat atau telah sesuai dengan teori Mintzberg yang membagi struktur organisasi pada umumnya ke dalam 5 (lima) elemen dasar, yaitu :

l) Strategic Apex, yaitu manajer tingkat puncak yang diberi tanggung jawab keseluruhan untuk organisasi itu,

2) Middle Line, yaitu para manajer yang menjadi penghubung antara strategic apex dengan operating core,

3) Techno Structure, yaitu para analis yang mempunyai tanggung jawab untuk melaksanakan bentuk standarisasi tertentu dalam organisasi,

4) Operating Core, yaitu para pegawai yang melaksanakan pekerjaan dasar yang berhubungan dengan produksi barang dan jasa, dan

5) Support Staff, yaitu orang-orang yang mengisi unit staf, yang memberi jasa pendukung tidak langsung kepada organisasi.

Dalam struktur birokrasi, Thoha (2006) menjelaskan bahwa perlu adanya perubahan yang meliputi 4 hal antara lain :

1) Right Sizing (Tepat Ukuran)

2) Ramping dan tidak terlalu banyak pembandingan secara horisontal.

3) Kaya Fungsi

4) Less Govern

Dengan berdasarkan pada berbagai peraturan serta terpenuhinya 5 elemen dasar dari teori

(1) Efektivitas Struktur Organisasi Perangkat Daerah (OPD)

Salah satu tujuan dari reformasi birokrasi ialah efektivitas kegiatan pemerintahan. Hal ini dapat tercermin dari pola struktur organisasi yang disusun oleh pemerintah baik pusat maupun daerah. Organisai yang mampu bertahan dan mampu memberikan kesuksesan pada pelaksanaannya yaitu organisasi yang yang tidak berbelitbelit serta mencakup semua jenis pekerjaan yang menjadi wewenang dan tugas di dalam organisasi tersebut.

Menurut Robbins (1994) efektifitas organisasi adalah sejauh mana sebuah oragnisasi mewujudkan tujuantujuannya. Pengertian ini sama dengan yang dikemukakn oleh Etzioni (1979) bahwa efektifitas aktual dari suatu organisasi tertentu ditentukan oleh tingkat sejauh mana organisasi tersebut merealisasikan tujuantujuannya. Gibson, mengemukakan empat pendekatan untuk mengeksplorasi keefektifan organisasi yaitu pendekatan pencapaian tujuan, pendekatan sistem, pendekatan konstituenti strategis dan pendekatan nilai-nilai bersaing. (Gibson, dkk. : 1985). Struktur OPD (Organisasi Perangkat Daerah) Kota Kendari, dianggap sudah efektif dengan penggunaan pola maksimal 12 bagian. Dan disusun berdasarkan peraturan yang ditetapkan oleh pemerintah pusat yaitu Peraturan Pemerintah No. 18 Tahun 2016 tentang Perangkat Daerah, yang selanjutnya di pemerintah Kota Kendari telah ditetapkan Perda No. 5 Tahun 2016 tentang Pembentukan dan Susunan Perangkat Daerah Kota Kendari. Hal ini menunjukan bahwa struktur Organisasi Perangkat Daerah Kota Kendari sudah sesuai dengan kebutuhan urusan pekerjaan yang ada di pemerintah Kota Kendari

\section{(2) Efisiensi Struktur Organisasi Perangkat Daerah}

Dalam struktur organisasi, prinsip efisiensi harus terus dilaksanakan demi tercapainya reformasi birokrasi. Efisiensi diartikan sebagai bagaimana ketepatan guna dalam organisasi itu bisa berjalan dengan apa yang sudah direncanakan sebelumnya serta berfungsi dengan baik, cepat dan tepat. struktur OPD Kota Kendari sudah 
efisien karena setiap tugas dan wewenang yang dikerjakan oleh masing-masing bagian dan sub bagian sudah berdasarkan peraturan dan pedoman bahwa pelaksana untuk tugas-tugas daerah itu harus dilaksanakan. Pelaksanaan tugas-tugas tersebut, tidak lain adalah kembali kepada pelayanan kepada masyarakat. Juga apabila dikaitkan dengan teori tentang konsep efisiensi yaitu bagaimana proses cara pelaksanaan struktur organisasi perangkat daerah Kota Kendari, maka struktur OPD Kota Kendari secara pandangan para informan sudah berjalan dengan efisien dan mengikuti arahan dari peraturan yang berlaku.

Sesuai dengan pengertian dari efisiensi organisasi yang dijelaskan oleh Atmosoepratmo (2001) bahwa pengertian dari efisiensi organisasi yaitu "how to do the things right" atau "Bagaimana kita mencampur berbagai sumberdaya secara benar. Oleh karenanya, arti efisiensi merujuk pada cara pelaksanaan kegiatan juga konsep efisiensi bersifat kuantitatif dan selalu dapat di ukur (Atmosoepratmo : 2001).

\section{(3) Produktifitas Kinerja Aparatur}

Menurut teori Rosen (1993), Konsep produktivitas dapat dipakai untuk menjelaskan bagaimana sumber-sumber daya digunakan secara optimal, sehingga dapat menghasilkan keluaran atau output yang maksimal (Rosen, 1993:4). Begitu pula yang di jelaskan oleh Denhardt (1991:268) dalam teorinya tentang produktivitas yang menyatakan bahwa public productivity berkaitan dengan bagaimana organisasi publik dapat mencapai tujuannya seefisien dan seefektif mungkin. Dengan demikian produktifitas kinerja tidak terlepas dari pada konsep efisiensi dan efektivitas - efisiensi bagi organisasi publik/pemerintah. produktifitas kinerja aparat seperti pemberian reward atau tunjangan yang kemudian menjadikan aparat lebih bersemangat dalam menjalankan tugasnya. Hal ini sesuai dengan teori bahwa untuk mencapai produktifitas, perlu dioptimalkan segala sumbersumber daya yang ada, sehingga pemberian reward yang merupakan sumber daya (money) kepada sumber daya (man) untuk mencapai hasil atau produktifitas yang optimal.

Dalam mencapai keberhasilan suatu reformasi birokrasi, dibutuhkan Keterlibatan dan Keseriusan unsur SDM melalui pencapaian output atau prestasi-prestasi gemilang para pegawai, unsur ini dikatakan sebagai faktor penting dalam sebuah organisasi. peningkatan produktifitas kinerja aparatur dalam Organisasi Perangkat Daerah Sekretariat Daerah Kota Kendari dilakukan dengan teknik peningkatan pada hal-hal yang dapat mempengaruhi produktifitas kinerja aparat seperti pemberian reward atau tunjangan yang kemudian menjadikan aparat lebih bersemangat dalam menjalankan tugasnya. Bentuk dari reward itu sendiri untuk mendukung prestasi kerja pegawai, yaitu diberikan berdasarkan sasaran kerja yang menerangkan apa yang dikerjakan pada hari itu terkait dengan tugas pokok dan fungsinya masing-masing sesuai dengan Srtuktur OPD yang ada. Juga bentuk punishment yang diberlakukan juga ada, yaitu pemberian sanksi-sanksi sesuai pelanggaran yang dilakukan, seperti tidak terselesaikannya tugas dengan baik sesuai dengan apa yang direncanakan sebelumnya, walaupun, sejauh ini belum ada yang benar-benar dengan sengaja meninggalkan pekerjaannya.

\section{Proses Pelimpahan Kewenangan terhadap Aparatur yang Ada di Bawahnya}

Dalam mencapai keberhasilan sebuah reformasi, dalam tubuh birokrasi juga harus ada kejelasan mengenai proses pelimpahan kewenangan antar aparatur, rantai komando serta rentang kendali yang jelas. Dalam pelimpahan kewenangan, didasarkan pada teknik atau rasionalitas tertentu yang menurut para ahli kebanyakan itu dipengaruhi oleh struktur dalam organisasi itu sendiri.

Pelimpahan wewenang pada dasarnya merupakan proses pengalihan tugas kepada orang lain yang sah atau terlegitimasi dalam melakukan berbagai aktivitas yang ditujukan untuk pencapaian tujuan organisasi yang jika tidak dilimpahkan akan menghambat proses pencapaian tujuan tersebut. Dalam pelimpahan kewenangan, 
didasarkan pada teknik atau rasionalitas tertentu yang menurut para ahli kebanyakan itu dipengaruhi oleh struktur dalam organisasi itu sendiri, dikatakan berdasarkan rasionalitas tertentu karena pada dasarnya banyak jenis dari struktur organisasi yaitu seperti :

1) Struktur organisasi lini

2) Struktur organisasi lini dan staf.

3) Struktur organisasi fungsional.

Juga banyak tokoh-tokoh pencetus teori ini yaitu Henry Fayol, yang dikenal sebagai pencipta teori organisasi bentuk lini, dan F.W. Taylor dengan teori organisasi fungsional

Proses pelimpahan kewenang pada Sekretariat Daerah Kota Kendari dilakukan dengan mengikuti prinsip rentang kendali dan rantai komando berdasarkan struktur yang sudah ada. Tugas-tugas sudah di bagi berdasarkan pendistribusian tugas dan urusan daerah yang harus diselesaikan oleh pemerintah Daerah. Setiap asisten membidangi 4 bagian yang sudah terdistribusikan dengan baik dan tidak akan pernah tumpang tindih antara satu bagian dengan bagian yang lain sehingga tidak ada urusan pemerintahan daerah yang tidak diurusi oleh pemerintah daerah.

\section{Kultur (Budaya Kerja) Birokrasi}

Dalam suatu reformasi birokrasi, khususnya pada budaya birokrasi Neo dan Chen (2007) mengemukakan bahwa institusi yang dinamis dicirikan dengan adanya ide baru, persepsi yang segar, up-grading yang berkelanjutan, aksi-aksi yang cepat, adaptasi yang fleksibel dan inovasi yang kreatif . institusi semacam ini akan melahirkan institusi yang selalu belajar, kebijakan yang cepat dan efektif dan perubahan yang tiada berakhir.

\section{(1) Penerapan Budaya Demokratis dalam Birokrasi}

Berdasarkan teori bahwa Budaya kerja Demokratis ialah adalah pola pikir dan budaya bekerja dengan berdasar pada nilai-nilai demokrasi, dan sikap beradasarkan nilai-nilai kemerdekaan, persamaan dan persaudaran antar manusia dengan kerjasama, saling percaya, toleransi, dan kompromi (Yudhi Hertanto : 2015).

Budaya Demokratis ialah budaya pelayanan yang baik dan keterbukaan kepada masyarakat selaku unsur yang dilayani. Pegawai yang melayani masyarakat yang dalam hal ini adalah pegawai Sekretariat Daerah Kota Kendari, sadar akan budaya ini demi tercapainya reformasi birokrasi yang salah satu unsur keberhasilannya terletak pada unsur SDM yaitu dari segi budaya yang diterapkan dalam organisasi oleh unsur-unsur manusia itu sendiri. Penerapan budaya demokratis pegawai Sekretariat Daerah Kota Kendari ialah baik. Hal ini sesuai dengan adanya pelayanan kepada masyarakat dalam bentuk keterbukaan informasi yang diberikan demi kebutuhan masyarakat. Bukan dengan adanya pemikiran "apa yang diperoleh dari pelayanan tersebut, melainkan bagaimana agar pelayanan tersebut memenuhi kebutuhan masyarakat.

\section{(2) Penerapan Budaya Profesional (Tidak ABS)}

Para pengemban profesi, diharapkan bekerja dengan kualitas yang baik sesuai yang duharapkan dari profesianya tersebut. Bukan hanya sekedar menjalankan tugasnya dengan benar tapi juga dengan baik dan menciptakan kualitas yang memuaskan. Inilah yang diharapkan dari sebuah reformasi birokrasi, khususnya dalam hal penataan budaya birokrasi. Penerapan budaya profesional di Sekretariat Daerah Kota Kendari, secara keseluruhan adalah cukup baik. Hal ini sesuai dengan penyelesaian berbagai tugas-tugas yang diberikan dan berbagai kewajiban-kewajiban yang harus dilaksanakan oleh pegawai sesuai denga tuntutan yang melekat pada profesinya yang dapat diatasi dan diselesaikan dengan baik. Namun, masih terdapat hambatan bagi budaya profesional ini yaitu terkait adanya sistem keterlibatan PNS dalam pemilihan kepala daerah yang selanjutnya, kepala daerah ini memiliki wewenang untuk mengangkat, memindahkan dan memberhentikan pegawai. Yang dimaksudkan sebagai hambatan ialah, ketika pegawai akan melakukan hal-hal yang dapat 
merusak integritas dan profesionalitas dirinya demi mendukung atau menyukseskan terpilihnya seorang calon kepala daerah.

Siagian (2000:163) menyatakan bahwa yang dimaksud dengan profesionalisme adalah "keandalan dalam pelaksanaan tugas sehingga terlaksana dengan mutu tinggi, waktu yang tepat, cermat, dan dengan prosedur yang mudah dipahami dan diikuti oleh pelaksana"

Berdasarkan teori di atas, para pengemban profesi, diharapkan bekerja dengan kualitas yang baik sesuai yang duharapkan dari profesianya tersebut. Bukan hanya sekedar menjalankan tugasnya dengan benar tapi juga dengan baik dan menciptakan kualitas yang memuaskan.

\section{(3) Penerapan Budaya Responsif dalam Birokrasi}

Yudhi Hertanto (2015) Berpendapat bahwa Responsif dalam makna bahwa organisasi tanggap secara bijaksana dalam melihat akan tanda perubahan dan tidak terlambat dalam mengantisipasi, namun tidak berarti reaktif yang cenderung emosional.

Teori di atas menerangkan makna responsif bahwa, organisasi harus mampu memberikan respon terhadap perubahan yang terjadi di lingkungan organisasi. hal ini tentu harus di mulai oleh unsur-unsur yang terdapat dalam organisasi tersebut. Bagaimana sumberdaya aparatur dapat dengan peka pelihat laju perkembangan zaman yang menuntut perubahan ke arah yang berbasis teknologi informasi. Oleh karenanya, yang dimaksud tanggap ialah meningkatkan kualitas diri dengan menyesuaikan perubahan perkembangan zaman, menguasai IT, tanggap terhadap tugas-tugas pokok dalam organisasi, dan tentu yang terpenting meningkatkan kualitas keimanan dan kesadaran demi tercapainya individu yang teintegritas dan tidak mudah dipengaruhi oleh pihakpihak yang lain.

Peningkatan sikap responsif dalam organisasi sangat diperlukan bagi tercapainya sebuah reformasi birokrasi. Sikap responsif ialah sikap memberikan reaksi dalam bentuk penyelesaian tugas-tugas dengan baik dan cepat serta tepat, juga tidak apatis dan diam saja dengan berbagai urusan-urusan yang seharusnya diselesaikan. Penerapan Budaya Responsif pegawai Sekretariat Kota Kendari ialah baik. pegawai Sekretariat Daerah Kota Kendari dalam menerima tugas yang diberikan sangat Responsif. Hal ini sangat jelas apabila tugas sudah diberikan atau didistribusikan untuk seluruh pegawai, dapat dengan baik diterima dan diselesaikan sesuai dengan prinsip pembagian kerja berdasarkan kewenangan yang dimiliki masing-masing bagian.

\section{KESIMPULAN}

Berdasarkan hasil penelitian dan uraian dalam pembahasan, maka dapat disimpulkan sebagai berikut :

1. Pelaksanaan reformasi birokrasi pada Sekretariat Daerah Kota Kendari melalui penataan kelembagaan sesuai teori Thoha (2006) yang meliputi Struktur Kelembagaan, Sistem yang digunakan dan perilaku SDM atau kultur birokrasi, sudah berjalan dengan baik sesuai dengan ketentuan penyusunan dan pelaksanaan reformasi birokrasi yang tercantum dalam Peraturan Presiden Republik Indonesia Nomor 81 tahun 2010 tentang Grand Design Reformasi Birokrasi 2010-2025 dan Kebijakan Permenpan dan RB NO. 20 TAHUN 2010 tentang Roadmap Reformasi Birokrasi 2010-2014.

2. Faktor-Faktor yang mempengaruhi pelaksanaan reformasi birokrasi melalui penataan kelembagaan pada Sekretariat Daerah Kota Kendari antara lain sebagai berikut :

a) Struktur OPD (Organisasi Perangkat Daerah) Kota Kendari, sudah disusun berdasarkan peraturan yang ditetapkan oleh pemerintah pusat yaitu Peraturan Pemerintah No. 18 Tahun 2016 tentang Perangkat Daerah, yang selanjutnya di pemerintah Kota Kendari telah ditetapkan Perda No. 5 Tahun 2016 tentang Pembentukan dan Susunan Perangkat Daerah Kota Kendari. Terkait efektivitas dan 
efisiensi, Struktur OPD (Organisasi Perangkat Daerah) Kota Kendari sudah sesuai dengan kebutuhan pekerjaan yang ada di pemerintah Kota Kendari sehingga dinilai sudah efektif dan tepat guna dalam menjalankan tugas-tugas pelaksanaan pemerintahan Kota Kendari juga struktur OPD Kota Kendari sudah efisien karena setiap tugas dan wewenang yang dikerjakan oleh masing-masing bagian dan sub bagian sudah berdasarkan peraturan dan pedoman bahwa pelaksana untuk tugas-tugas daerah itu harus dilaksanakan. Pelaksanaan tugas-tugas tersebut, tidak lain adalah kembali kepada pelayanan pada masyarakat.

b) Proses Pelimpahan Kewenangan terhadapan aparatur ialah disesuaikan dengan prinsip rentang kendali dan rantai komando dari struktur organisasi itu sendiri. Proses penyusunan struktur yang berdasarkan atas peraturan yang ditetapkan langsung dari pemerintah pusat, menjadikan proses pelimpahan kewenangan yang jadi lebih terarah dan juga terkait pendistribusian tugas yang tidak akan saling tumpang tindih antara satu dengan yang lainnya.

c) Kultur atau budaya kerja pada Sekretariat Daerah Kota Kendari, yang berkaitan dengan tiga hal utama yaitu Budaya Demokratis, meskipun terdapat berbagai perbedaan karakter setiap orang dalam bertindak dan berperilaku, namun secara keseluruhan, dalam hal pelayanan, dan keterbukaan kepada masyarakat, maka perbedaan-perbedaan persepsi dan karakter ini bukanlah masalah besar dan dapat dikatakan bahwa penerapan budaya Demokratis pegawai Sekretariat Daerah Kota Kendari sudah cukup baik. Kemudian Terkait Budaya Profesional (tidak ABS/Asal Bapak Senang), di Sekretariat Daerah Kota Kendari sudah cukup baik walaupun masih ada sedikit hambatan dalam sistem yang dikatakan melukai citra profesi pegawai. Hal ini karena mau-tidak mau selalu saja adanya oknumoknum aparat yang tidak netral dalam bekerja yang dapat dengan mudah menggadaikan profesinya demi jabatan dan rupiah, itulah yang seharusnya ditindaki secara tegas. Namun, secara keseluruhan terlepas dari semua itu, dan juga sesuai pengamatan yang dilakukan maka terkait pelayanan kepada masyarakat sebagai tuntutan dari profesi, dapat dikatakan bahwa penerapan budaya Profesional di Sekretariat Daerah Kota Kendari sudah cukup baik. Kemudian Menyangkut Budaya Responsif yaitu sangat baik. Hal ini sesuai dengan keterangan yang diberikan oleh beberapa informan juga hasil pengamatan yang dilakukan terlihat bahwa pegawai Sekretariat Daerah Kota Kendari sangat baik dan sangat responsif terhadap tugas tugas yang diberikan yang sesuai dengan kewenangan yang dimiliki pada setiap bagian.

\section{SARAN}

Sebagai aktor pemerintahan, para birokrat atau pelaku yang memegang kendali dalam sebuah birokrasi, yaitu pegawai Sekretariat Dearah Kota Kendari seharusnya dapat menjalankan penataan birokrasi dengan sebaik mungkin mengikuti prinsip-prinsip reformasi yang dicanangkan demi tercapainya birokrasi yang bersih, efektif, efisien, produktif dan berdaya saing tinggi. Penataan yang dilakukan baik dari segi struktur maupun kultur (budaya) haruslah dapat memberikan pengaruh yang baik pada birokrasi itu sendiri. Pengaturan berbagai pelaksanaan kelembagaan yang efektif dan efisien dan penyederhanaan ketatalaksanaan yang sesuai dengan pedoman yang telah disepakati dan direncanakan, maupun penataan budaya organisasi yang baik. Sedapat mungkin Pegawai Sekretariat Dearah Kota Kendari harus netral dalam menjalankan tugas administrasi dalam birokrasi. Jangan mudah terpengaruhi oleh hal-hal yang dapat melukai citra birokrasi yang bisa menyebabkan keadaan semakin buruk, sampai pada kemungkinan mengancam keamanan dan kenyamanan pelaksanaan 
pemerintahan daerah Kota Kendari. Oleh Karena itu, diharapkan sebagai aktor-aktor pelaksana Birokrasi pemerintahan, Penataan Kelembagaan di Sekretariat Dearah Kota Kendari dapat memenuhi proses perkembangan Reformasi Birokrasi baik di daerah ataupun secara skala Nasional.

\section{DAFTAR PUSTAKA}

\section{Buku}

Thoha, Miftah.2006. Demokrasi dalam Birokrasi Pemerintah : Peran Kontrol Rakyat dan Netralitas Birokrasi dalam Dari Administrasi Negara ke Administrasi Publi. Gadjah Mada University Press Yogyakarta.

Agun Gunandjar.2012.Urgensi Reformasi Birokrasi.Pusat Dokumentasi Dan Informasi Hukum Nasional : Media Indonesia

Asep Muhammad.2018.Memahami Reformasi Birokrasi. Pusat Teknologi Informasi dan Komunikasi Perhubungan (dephub.go.id))

Fountain, J.E. 2007. Bureaucratic Reform and E-Government in the United States : An Institutional Perspective. A prepublication version of a chapter to be printed Andrew Chandwick and Philip N. Howard (Eds). The Handbook of Internet Politics. New York : Routledge.

Haryanto (ClAl 13 027). 2017. Pelaksanaan Fungsi Pengawasan dalam Meningkatkan Efektivitas Kerja Pegawai Sekretariat Daerah Kota Kendari. Jurusan Administrasi Negara, Fakultas Ilmu Administrasi, Universitas Halu Oleo

Muhammad Amir.2015.Reformasi Birokrasi Perspektif Neo Weberian State, Teori, Konsep dan Aplikasi.Surabaya ; Jenggala Pustaka Utama

Sedarmayanti.2008.Manajemen Sumber Daya Manusia, Reformasi Birokrasi dan Manajemen Pegawai Negeri Sipil

\section{Undang-Undang / Peraturan}

Peraturan Presiden Republik Indonesia Nomor 81 tahun 2010 tentang Grand Design Reformasi Birokrasi 20102025

Permenpan dan RB NO. 20 TAHUN 2010 tentang Roadmap Reformasi Birokrasi 2010-2014

UU No. 23 Tahun 2014 tentang Pemerintahan Daerah yaitu pada Bab VIII tentang Perangkat Daerah

Peraturan Pemerintah No. 18 Tahun 2016 tentang Perangkat Daerah

Roadmap Reformasi Birokrasi Kota Kendari tahun 2015-2019

PERDA Kota Kendari No. 5 Tahun 2016 tentang Susunan Perangkat Daerah

PERWALI No. 36 Tahun 2016 tentang Kedudukan, Susunan Organisasi, Tugas dan Fungsi serta Tata Kerja Sekretariat Daerah. 